\title{
Review
}

\section{Flattery and the history of political thought: That Glib and Oily Art}

\author{
Daniel J. Kapust \\ Cambridge University Press, Cambridge, 2018, v + 230pp., \\ ISBN: 9781107043367
}

Contemporary Political Theory (2019) 18, S263-S266. https://doi.org/10.1057/s41296018-0242-3; published online 12 July 2018

It is a piece of conventional wisdom that the word 'flatterer' is an insult, not a term of endearment. The commonly used words 'kiss-ass', and 'suck up', silently uttered or expressed in a loud voice as a reaction to performances of sycophancy, convey our despair of flatterers and suggest this much. In political theory, Daniel Kapust reminds us in Flattery and the History of Political Thought: That Glib and Oily Art, flatterers have not fared much better. The prevalent view of flattery, traced to the earliest philosophical treatments of that phenomenon, denounces flattery as immoral tout court - a denunciation which is sustained by a juxtaposition between kolakeia (flattery) and the ideal of parrhesia (frank speech) (Plato, 1987; Plutarch, 1949). The long-standing denunciation of flattery notwithstanding, that phenomenon was, at least, treated as an important moral and political problem. What is puzzling is that flattery, though ubiquitous in political life, has received little attention by political theorists today.

This recognition animates Kapust's captivating book, the aim of which is to give flattery its due, and fill a lacuna in political thought. Via a meticulous enquiry into a range of figures, periods, arguments and interpretations expertly drawn from novel readings of classical works in political thought, works of literature, tales and fables, Kapust offers a thought-provoking historical and theoretical treatment of flattery, which grapples with its peculiar nature and its intricate relationship with other forms of speech (hypocrisy, lying and bullshit), fleshing out, with precision, its different facets and functions.

For those self-assured proponents of the negative or moralistic view of flattery, Kapust's book bears uncomfortable news. Or, so it would seem. The main thesis is that 'we should not label flattery as morally and politically bad per se' (p. 11). To acknowledge that point and presuppose that one has ascertained some important truth, will not, however, do. For, whilst we should not 'label flattery as a vice, tout court' (p. 13), not all flattery is desirable. In short, Kapust does not reject the moralistic account of flattery in toto; flattery might be problematic, especially when

(C) 2018 Springer Nature Limited. 1470-8914 Contemporary Political Theory Vol. 18, S4, S263-S266 
virtuosos of flattery employ 'insincere praise ... [which] may harm those to whom it is applied' or 'manipulate them into doing what they would not otherwise do' ( $\mathrm{p}$. 24). Kapust thus sets out to show that whilst most political thought scorns flattery 'matters are much more complicated' (p. 25).

What complicates matters is not just that flattery poses different challenges to different contexts - challenges which Kapust expertly brings to light - but rather the recognition that the question of whether flattery is reprehensible cannot be addressed in abstracto of the messiness of politics, and without addressing the prior questions of 'what [flattery] does, who is doing it, and why' (p. 26). Kapust's integration of an admirable command of historical detail and philosophical analysis thus proceeds by approaching flattery via a non-ideal lens. His analysis runs counter to the aspirations of ideal paradigms of deliberative democracy which, be they Rawlsian or Habermasian, put forward a sanitised, apolitical vision of communication sustained by a belief in consensus. These paradigms highlight the unconditional value of truthfulness and scorn the strategic employment of discourse, i.e. the treatment of one's audience and interlocutors as objects to be manipulated or subdued. Echoing the mantra of the recent realist turn in political theory, Kapust's analysis endeavours to be attentive to the grubbiness of politics: 'political life', he emphasises, 'is about friction' (p. 202). As such, 'our institutions and the "social facts" in which they - and we are - embedded ... remind us, when encountering the place of flattery in the history of political thought, of the importance of the non-ideal' - the permanence of 'dependence, inequality, and hierarchy' (pp. 202-203).

Adopting a non-ideal perspective, Kapust distinguishes between cunning flatterers - the object of moralist scorn - and dependent flatterers whose flattery is not fuelled by avarice, but by 'the precariousness of their social status' (p. 4). The latter, Kapust maintains, are less bothersome than the former as 'overt deference' might form 'a protective barrier that surrounds dominated persons' (p. 8). Taking his cue from Scott's $(1985,1990)$ distinction between public transcripts - the public performances of the weak which create the superficial impression of wilful submission to the powerful - and hidden transcripts - off-stage critiques of power Kapust suggests that flattery can function as a weapon of the weak, a coping strategy in conditions of subordination.

The discussion unfolds in five core chapters which interrogate flattery via the establishment of dialogue between conceptually and linguistically overlapping works in the history of political thought. Chapter 1 explores the connection between flattery, equality and legitimacy via a comparative study of Cicero and Pliny. By treating Cicero's and Pliny's speeches as public transcripts, Kapust illustrates how Roman republican anxieties 'about status and power inequalities' connection to flattery and tyranny' and the corrosive effects of such inequalities on friendship and frank speech formed the ideological foundation for the princeps' legitimacy - an idealised account of the relationship between rulers and ruled 
which legitimised otherwise intolerable inequalities "by the presence of friendship and the absence of flattery' (p. 61). Chapter 2 considers the relationship between flattery and modes of discourse, especially courtly style. To that end, Kapust turns to Machiavelli and Castiglione who seek to 'understand and prevent the harms of flattery, harms that were quite likely to redound princes' and who articulate contrasting accounts of the virtuous advisor (p. 200). Castiglione's ideal courtier 'captivates to instruct': he utilises pleasing ornament which enables him to manipulate the prince into accepting his harsh, albeit necessary, teachings, and into doing what he should have done. Machiavelli, in contrast, 'instructs to captivate': he rejects ornament and utilises an unflattering style, captivating his audience via an open display of his learning (p. 65).

The discussion then turns to the connection between flattery and types of political authority. By engaging imaginatively with Hobbes's thought, Kapust illustrates that Hobbes's defence of monarchy rests on his scepticism about participatory governments and an appreciation of the political dangers of flattery. Monarchy is less susceptible to flattery because it is contingently unitary: the unity of the natural and the artificial person of the sovereign representative constitutes a bulwark against 'rhetorical appeals', sparked by 'desire to win for private gain', which typify plural sovereigns (p. 118). Chapter 4 explores flattery qua element of theories of language and identity formation via a comparative reading of Mandeville and Smith. At the core of Mandeville's instrumentalist suggestion that flattery constitutes an agent of socialisation, Kapust argues, lies a bleak account of human nature and sociability: flattery is 'an outgrowth of language' which is 'manipulative' and which is rooted in 'our desire to control others and confirm our own sense of worth' (p. 168). Smith proceeds in the opposite way: flattery is a manifestation of our natural sociability - our capacity for sympathy, love of praiseworthiness and endeavour to establish relationships of mutual agreement, not of domination. Chapter 5 centres on the accusations of flattery as a political tactic, with a focus on the ratification debates. What animated that rhetorical battle, Kapust argues, was not merely the endeavour to denigrate one's opponents as obsequious, but rather two contrasting visions of what America was, and what it would (or could) be. For, the Federalists denounced the Anti-Federalist commitment to local bonds and liberties as 'flattery of prejudice' - the pandering to local prejudices which would engender fragmentation and frailty (p. 179). The Anti-Federalists, in turn, accused the Federalists for promising a romantic future of greatness, empire and unity which would eradicate liberty and difference.

Whilst Kapust cruises effortlessly through the history of political thought, a less flattering reviewer would, perhaps, ask for more. For instance, the suggestion that Smith's theory stems from within politics is underdeveloped, perhaps unwarranted, given its hypothetical foundations. More importantly, the core promise of the book - the endeavour to challenge the moralistic view - does not fully materialise. This is not just because Kapust remains immersed in historical articulations of the

(C) 2018 Springer Nature Limited. 1470-8914 Contemporary Political Theory Vol. 18, S4, S263-S266 S265 
moralistic account - as he acknowledges 'whether it was Cicero, Pliny, Castiglione, Machiavelli, or Hobbes, flattery was a bad thing', either morally and/or politically, and only Mandeville, from the authors surveyed, 'seems to view flattery as a good thing' (p. 138). Rather, the trouble is that, whilst Kapust shows that flattery can be a tactic used by the less powerful, he does not convincingly illustrate how it can be a weapon of the weak. Cicero's and Pliny's ideal rulers and ruled, Castiglione's ideal courtier and Smith's and Mandeville's commercial agents operate amid conditions of dependence and/or inequality, not of servitude. Kapusts's agents are political somebodies - they hold some political power, regardless of how small that slice of power might be - and employ flattery to advance the public good; they are not political nobodies - persecuted or excluded - employing flattery to challenge power and disrupt radical injustice. The aforementioned problem is magnified by the allmale and all-white line-up, and the corresponding omission of the perspectives and experiences of historically excluded and marginalised groups - slave and women narratives, and black and feminist political thought.

These issues aside, this is an impressively rich book which will be of interest to scholars concerned with problems of flattery, and those immersed in the history of political thought and the ideal/non-ideal theory debate.

\section{References}

Plato. (1987). Gorgias, Translated by D.J. Zeyl Indianapolis, IN: Hackett.

Plutarch. (1949). How to Tell a Flatterer from a friend, Translated by F.C. Babbit Cambridge, MA: Harvard University Press.

Scott, J. C. (1985). Weapons of the weak: Everyday forms of peasant resistance. New Haven, CT: Yale University Press.

Scott, J. C. (1990). Domination and the art of resistance: Hidden transcripts. New Haven, CT: Yale University Press.

Demetris Tillyris

Canterbury Christ Church University, Canterbury CT1 1QU, UK demetris.tillyris@canterbury.ac.uk 